\title{
FNVIROMMEETTHL

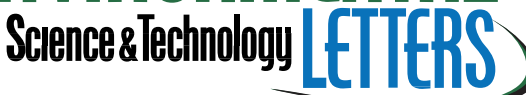

\section{Historical Trends of Biogenic SOA Tracers in an Ice Core from Kamchatka Peninsula}

\author{
3 Pingqing Fu, ${ }^{* \dagger, \$}$ Kimitaka Kawamura, ${ }^{\dagger}$ Osamu Seki, ${ }^{\dagger}$ Yusuke Izawa, $^{\dagger}$ Takayuki Shiraiwa, \\ 4 and Kirsti Ashworth ${ }^{\S}$
}

$5{ }^{\dagger}$ Institute of Low Temperature Science, Hokkaido University, Sapporo 060-0819, Japan

$6{ }^{*}$ LAPC, Institute of Atmospheric Physics, Chinese Academy of Sciences, Beijing 100029, China

$7{ }^{\S}$ Biosphere-Atmosphere Interactions Group, Climate and Space Sciences and Engineering (CLaSP), University of Michigan, Ann

8 Arbor, Michigan 48109-2143, United States

\section{S Supporting Information}

10 ABSTRACT: Biogenic secondary organic aerosol (SOA) is ubiquitous in the Earth's atmosphere, influencing climate and air quality. However, the historical trend of biogenic SOA is not well known. Here, we report for the first time the major isoprene- and monoterpene-derived SOA tracers preserved in an ice core from the Kamchatka Peninsula. Significant variations are recorded during the past 300 years with lower concentrations in the early-to-middle 19th century and higher concentrations in the preindustrial period and the present day. We discovered that isoprene SOA tracers were more abundant in the preindustrial period than the present day, while monoterpene SOA tracers stay almost unchanged. The causes of the observed variability are complex, depending on atmospheric circulation, changes in emissions, and other factors such as tropospheric oxidative capacity. Our data presents an unprecedented opportunity to shed light on the formation, evolution, and fate of atmospheric aerosols and to constrain the uncertainties associated with modeling their atmospheric concentrations.
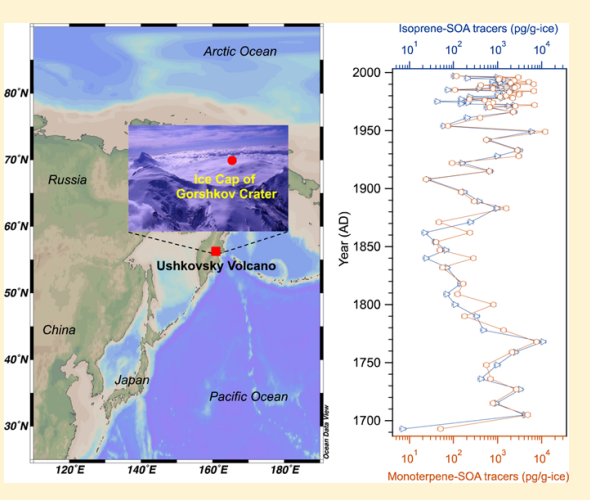

\section{INTRODUCTION}

26 Palaeoclimate archives containing annual layers (e.g., ice cores, 27 tree rings, speleothems, and coral reefs) have played a central 28 role in reconstructing decadal-scale climatic oscillation of the 29 past. ${ }^{1}$ This insight has proved an invaluable tool to constrain 30 climate model projections of future climate change by 31 validating model hindcasts. Similarly, analysis of particles 32 preserved in ice cores provides an unprecedented opportunity 33 to elucidate the distribution, concentration, size distribution, 34 and even chemical composition of atmospheric aerosols in the 35 past. Such data would allow us to deduce the influence of 36 aerosol radiative forcing on past climate change. Previously, 37 aerosol particles preserved in high altitudinal or high latitudinal 38 ice cores have been examined for inorganic species (e.g., 39 sulfate), black carbon, and organic species such as polycyclic 40 aromatic hydrocarbons, carboxylic acids, biomass burning 41 tracers, and humic-like substances. ${ }^{2-7}$ To date, little was 42 known about the historical trends of secondary organic aerosols 43 at a molecular level. ${ }^{3,8}$ Here, we present the findings of the 44 analysis of ice cores for evidence of organic compounds formed 45 from biogenic trace gases.

46 Terrestrial vegetation emits large quantities $\left(\sim 1 \mathrm{Pg} \mathrm{C} \mathrm{y}^{-1}\right)$ of 47 biogenic volatile organic compounds (BVOCs), including 48 reactive species such as isoprene and monoterpenes, to the 49 atmosphere. ${ }^{9}$ The role of their atmospheric reactions in governing the production and loss of tropospheric ozone is 50 well studied and relatively well understood, but BVOC 51 oxidation has also been shown to lead to aerosol 52 formation. ${ }^{10-12}$ Organic particles formed by the photooxidation 53 of BVOCs are considered "secondary" organic aerosols (SOA) 54 and are believed to be more abundant than directly emitted 55 "primary" organic aerosols (POA) in the Earth's atmos- 56 phere. ${ }^{11,13-16}$ It is believed that SOA could be a significant 57 source of new nanoscale particles, especially in pristine remote 58 regions, ${ }^{17,18}$ that can grow into the accumulation mode and act 59 as $\mathrm{CCN}$, influencing local climate and radiative forcing. 60 However, the uncertainties are substantial. Estimates of 61 biogenic SOA production range from 9-910 $\mathrm{Tg} \mathrm{C} \mathrm{y}^{-1}$ with a 62 best estimate of $60-240 \mathrm{Tg} \mathrm{C} \mathrm{y}^{-1} \cdot{ }^{11,19-21}$ The radiative forcing 63 effect of SOA has been estimated as $-0.03 \mathrm{~W} \mathrm{~m}^{-2}(-0.27$ to 64 $\left.+0.20 \mathrm{~W} \mathrm{~m}^{-2}\right),{ }^{22,23}$ but this is highly dependent on assumptions 65 of the total atmospheric burden of SOA.

Given the ubiquity and influence of organic particles in the 67 atmosphere, there is an urgent need to better understand and 68 constrain the processes leading to the formation of SOA and to 69

Received: July 20, 2016

Revised: August 27, 2016

Accepted: August 30, 2016 


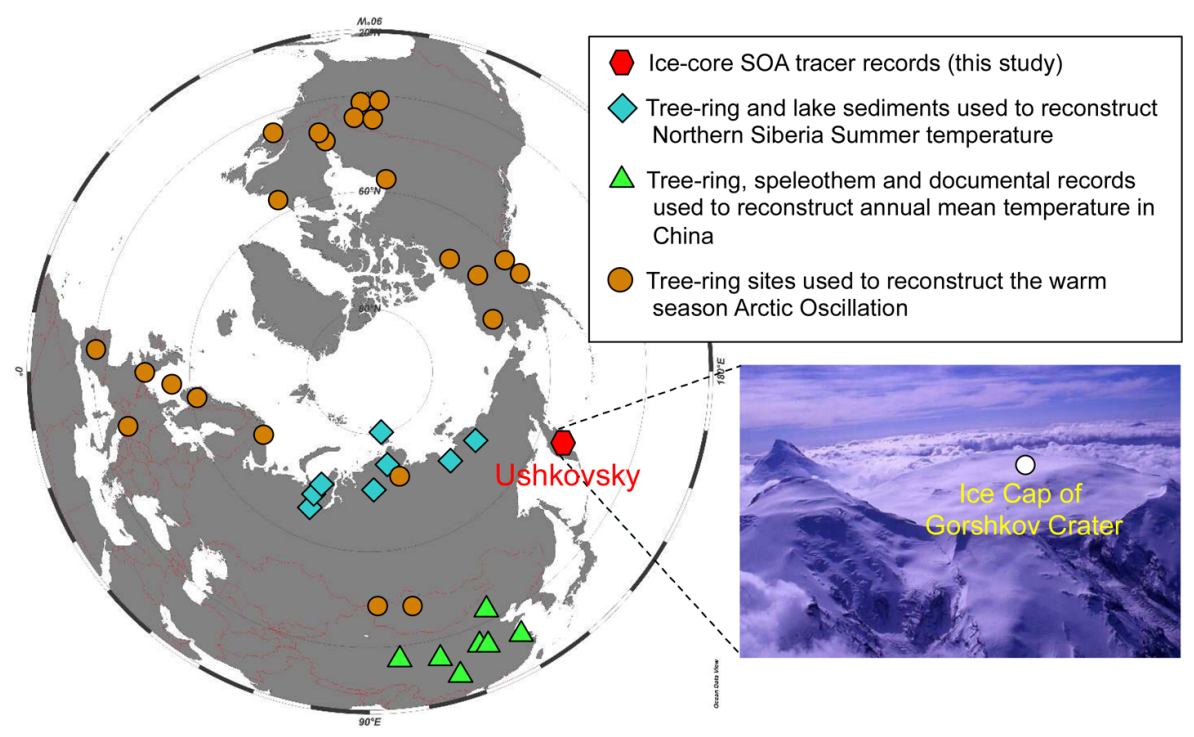

Figure 1. Sampling site of the ice core $(211.7 \mathrm{~m}$ long $)$ at the ice cap of the Gorshkov crater at the Ushkovsky Volcano $\left(56^{\circ} 04^{\prime} \mathrm{N}, 160^{\circ} 28^{\prime} \mathrm{E} ; 3903 \mathrm{~m}\right.$ a.s.l.), Kamchatka Peninsula. In this study, we used ice core sections from depths from 1.32 to $152.5 \mathrm{~m}$ (1997-1693). The deeper sections were not used because of the presence of many sand layers; their data are presented in Table S1. The ice core chronology was determined by counting the annual layers of a seasonal oxygen isotopic signal $\left(\delta^{18} \mathrm{O}\right)$ from the surface to a depth of $103.58 \mathrm{~m}$, whereas the chronology for deeper layers was determined using a two-dimensional thermodynamic coupled model. ${ }^{33}$ Sites used for reconstruction of the Northern Hemispheric temperatures (Figure 2D,E) are also shown in the map.

70 elucidate the role of aerosols in governing global and regional 71 climate. Studies of production, transformation, and removal 72 processes have been extensively conducted for ambient aerosols 73 and simulated in laboratory conditions. ${ }^{24-28}$ Relationships 74 between the phases of organic aerosols and their reactivity ${ }^{29,30}$ 75 have been investigated. Model simulations have been 76 performed to identify trends in SOA concentrations and 77 distributions and to quantify modern and past SOA 78 budgets. ${ }^{31,32}$ However, the uncertainties of such estimates are 79 substantial, and better constraints are required.

80 Here, we report 300 years of ice core records of biogenic 81 SOA based on organic marker compounds produced by the 82 oxidation of isoprene and monoterpenes from the Ushkovsky 83 ice cap in Northeast Asia (Figure 1). Such data represent a 84 potential source of direct evidence of biogenic SOA 85 concentrations and chemical properties that could be used to 86 evaluate model hindcasts and constrain model projections of 87 future budgets and radiative forcing of atmospheric aerosols.

\section{MATERIALS AND METHODS}

Study Area. The ice core (211.7 m long) was drilled from 90 the ice cap of the Gorshkov crater at Ushkovsky volcano $91\left(56^{\circ} 04^{\prime} \mathrm{N}, 160^{\circ} 28^{\prime} \mathrm{E} ; 3903 \mathrm{~m}\right.$ a.s.l. $)$ in the central part of the 92 Kamchatka Peninsula, Russia (Figure 1). Detailed ice core 93 chronology $^{33}$ and analytical methodology are provided in the 94 Supporting Information (SI). Here, 75 sections were cut off 95 using a band saw. Ice core sections $(50 \mathrm{~cm}$ long, $1 / 4 \mathrm{cut})$ were 96 taken at every $1 \mathrm{~m}$ for the upper $25 \mathrm{~m}$ and at every $4-5 \mathrm{~m}$ for 97 the layers deeper than $25 \mathrm{~m}$. Approximately $1.0 \mathrm{~cm}$ thickness of 98 the outer core surface was mechanically removed using a 99 precleaned ceramic knife in a cold clean room to avoid 100 potential contamination.

101 Bulk Analysis. Each sample section was melted in a 102 precleaned Pyrex beaker $(2 \mathrm{~L})$. The samples were poisoned 103 with $\mathrm{HgCl}_{2}$ to prevent potential microbial degradation of 104 organic compounds and stored at $4{ }^{\circ} \mathrm{C}$ in precleaned brown glass bottles prior to analysis. In this study, we use 59 samples 105 collected from 1.1 to $152.6 \mathrm{~m}$ in depth (1997-1693); the data 106 of deeper sections (Table S1) were not used because of the 107 presence of many sand layers.

The meltwater samples were transferred to a pear-shaped 109 flask and concentrated to almost complete dryness using a 110 rotary evaporator under a vacuum. The total organic matter in 111 the dried samples was extracted with a 2:1 v/v solution of 112 $\mathrm{CH}_{2} \mathrm{Cl}_{2} / \mathrm{CH}_{3} \mathrm{OH}$ using an ultrasonic bath. The extracts were 113 concentrated and passed through a glass column packed with 114 quartz wool and further eluted with $\mathrm{CH}_{2} \mathrm{Cl}_{2}$ and $\mathrm{CH}_{3} \mathrm{OH}$ to 115 extract the organics potentially adsorbed on the particles. The 116 eluents were then combined with the extracts, transferred to 1.5117 $\mathrm{mL}$ glass vials, and dried under a pure nitrogen gas stream. 118 Polar organic markers in the extracts were derivatized with 99\% 119 N,O-bis(trimethylsilyl)trifluoroacetamide (BSTFA) and $1 \% 120$ trimethylsilyl chloride for $2 \mathrm{~h}$ at $70{ }^{\circ} \mathrm{C}$ in a sealed glass vial 121 $(1.5 \mathrm{~mL})$. The derivatives were then diluted by the addition of 122 $n$-hexane containing $\mathrm{C}_{13} n$-alkane as an internal standard prior 123 to the determination by gas chromatography-mass spectrom- 124 etry (GC-MS).

GC-MS Measurement. GC-MS analyses were performed 126 on a Hewlett-Packard model 6890 GC coupled to a Hewlett- 127 Packard model 5973 MSD with a programmed GC oven 128 temperature. Target compounds were identified by comparing 129 the mass spectra with those of authentic standards or data in 130 the literature. ${ }^{24,34}$ Recoveries for the standards or surrogates 131 were better than $80 \%$. The analytical errors in triplicate analyses 132 were within $15 \%$. A laboratory blank was measured using Milli- 133 Q water and showed no contamination for any target species. 134

\section{RESULTS}

The total concentrations of biogenic SOA tracers (Figure 2A,B $136 \mathrm{f} 2$ and Table S2) detected in the Ushkovsky ice cores range widely 137 (50.2-18,400 pg/g-ice; mean $2890 \mathrm{pg} / \mathrm{g}$-ice), covering the 138 period between 1693 and present day (1997). The enlarged 139 


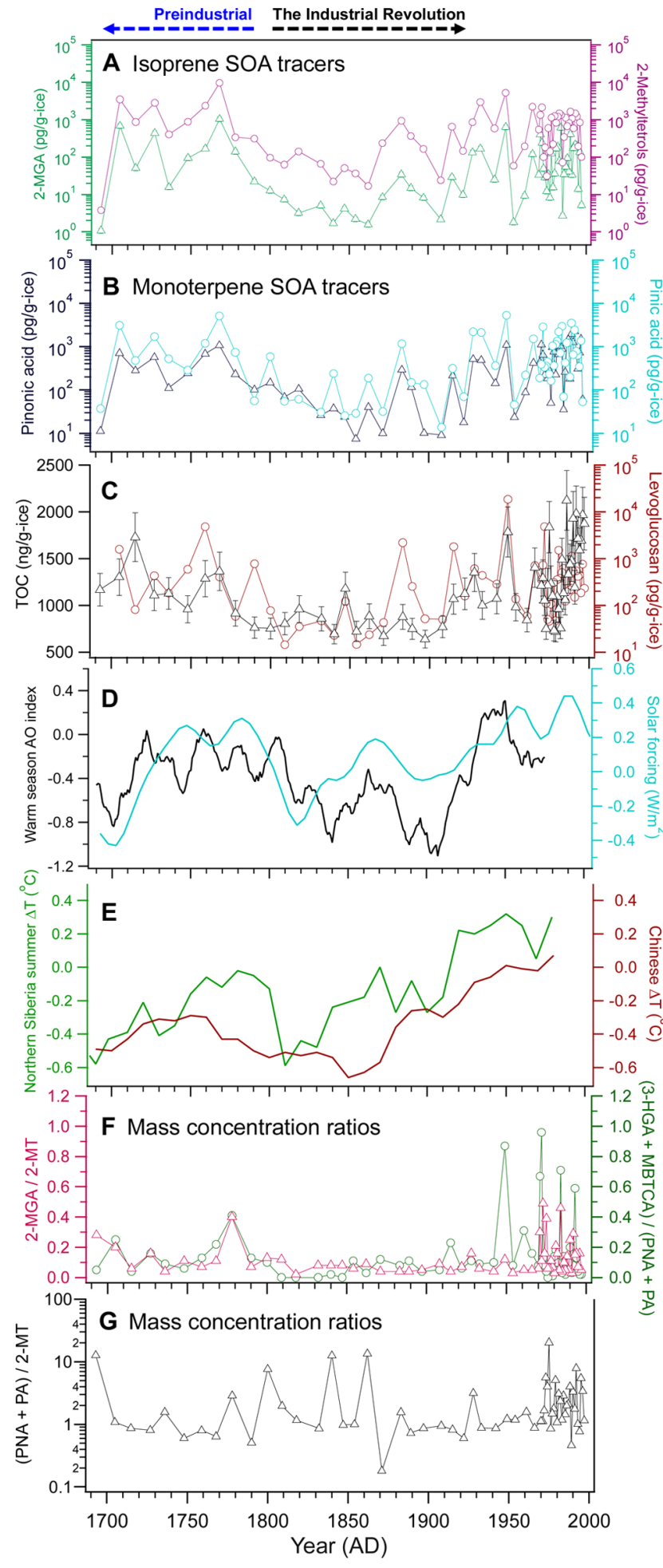

Figure 2. (A) and (B) Historical trends in the concentrations of isoprene secondary organic aerosol (SOA) tracers and monoterpene SOA tracers in the Ushkovsky ice core, respectively. (C) Historical trends in the concentrations of total organic carbon (TOC) and levoglucosan, as reported by Kawamura et al. ${ }^{4}$ (D) Reconstructed warm season Arctic Oscillation (AO) index ${ }^{54}$ and solar radiative forcing. ${ }^{70}$ (E) Reconstructed Northern Siberian and Chinese summer temperatures. $^{51}(\mathrm{~F})$ and $(\mathrm{G})$ Historical changes in the mass concentration ratios among different organic marker compounds measured in the Ushkovsky ice core. figure covering the period of $1950-1997$ is provided in the 140 Supporting Information (Figure S2). The data are strongly 141 positively skewed (median $3750 \mathrm{pg} / \mathrm{g}$-ice; 10th and 90th 142 percentiles, $179 \mathrm{pg} / \mathrm{g}$-ice and $6230 \mathrm{pg} / \mathrm{g}$-ice, respectively) due 143 to anomalously high concentrations in a handful of years during 144 the preindustrial (1693-1790) and the 20th century (1908- 145 1997 ) periods, notably 1768 and 1949. Concentrations of total 146 organic carbon (Figure 2C) as well as those of individual tracers 147 were lowest in the 19th century and, in particular, during the 148 peak of the Little Ice Age in Europe (early mid 1800s), when 149 temperatures were low throughout the biogenic source regions 150 suppressing emissions. ${ }^{35,36}$ On the whole, there is a strong 151 correlation between ice core SOA tracer concentrations and the 152 Northern Hemisphere high-latitude temperature anomaly and a 153 weak correlation with solar irradiance (Figure 2A-E). While 154 concentrations of the individual tracers fit this general pattern, 155 there are also notable differences, which are discussed later. 156

Isoprene SOA Tracers. Oxidation products of isoprene, the 157 most prevalent nonmethane hydrocarbon emitted to the 158 atmosphere, ${ }^{37}$ have been shown to be significant contributors 159 to global organic aerosol mass. ${ }^{24,38}$ Concentrations of 2- 160 methyltetrols (2-MT), the sum of 2-methylthreitol and 2- 161 methylerythritol, in the Ushkovsky ice core ranged from 3.8 to 162 $9710 \mathrm{pg} / \mathrm{g}$-ice (median $587.5 \mathrm{pg} / \mathrm{g}$-ice; Table S2). 2-MT, 163 together with $\mathrm{C}_{5}$-alkene triols and 3-methyltetrahydrofuran-3,4- 164 diols (3-MeTHF-3,4-diols) neither of which were detected in 165 the Ushkovsky ice core, are higher generation products formed 166 from the photooxidation of epoxydiols of isoprene (IEPOX $=167$ $\beta$-IEPOX $+\alpha$-IEPOX $)$ under low- $\mathrm{NO}_{x}\left(\mathrm{NO}_{x}=\mathrm{NO}+\mathrm{NO}_{2}\right)$ or 168 $\mathrm{NO}_{x}$-free conditions. ${ }^{39}$ In this study, 2-MT concentrations in 169 the preindustrial period were about double those in the 20th 170 century and more than 30 times higher than those during the 171 end of Little Ice Age (early-to-middle 1800s). As expected, a 172 strong correlation $\left(R^{2}=0.95, p<0.05\right)$ was found between $2-173$ methylerythritol and 2-methylthreitol (Figure S1), with the 174 isomeric fractions of 2-methylerythritol in 2-MT varying little 175 between the different periods $(\sim 0.70 \pm 0.04)$.

By contrast, 2-methylglyceric acid (2-MGA) is a $\mathrm{C}_{4^{-}} 177$ dihydroxycarboxylic acid that is formed via methacrylic acid 178 epoxide (MAE) and has been identified as a key gas-phase 179 intermediate resulting in isoprene SOA formation from the 180 high- $\mathrm{NO}_{x}$ pathway. ${ }^{40,41}$ In the preindustrial period, $\mathrm{NO}_{x} 181$ emissions were limited to wildfires, soil denitrification, and 182 lightning. ${ }^{42}$ The large rise in anthropogenic $\mathrm{NO}_{x}$ emissions 183 since the start of the industrial revolution ${ }^{43}$ have increased 184 atmospheric $\mathrm{NO}_{x}$ concentrations; yields of 2-MGA would have 185 been expected to be more substantial in the present day than in 186 the preindustrial period. However, 2-MGA was found to be less 187 abundant than 2-MT in all core samples, varying from 0.03 to 188 0.86 (mean ratio of 2-MGA:2-MT $\sim 0.13$ ). The mean ratios of 189 2-MGA/2-MT showed only negligible differences between the 190 present $(0.13)$ and the preindustrial period $(0.15)$ but were 191 slightly lower in the early-to-middle 1800s $(\sim 0.08)$. These 192 results suggest that the low-NO $\mathrm{NO}_{x}$ pathway via IEPOX ${ }^{39,41,44-46} 193$ has dominated isoprene photooxidation at the high latitudes in 194 the Northern Hemisphere throughout the past three centuries. 195

Monoterpene SOA Tracers. We detected four mono- 196 terpene oxidation products in the ice core samples: 3- 197 hydroxyglutaric acid (3-HGA), pinonic acid, pinic acid, and 198 3-methyl-1,2,3-butanetricarboxylic acid (MBTCA). Pinic and 199 pinonic acids (PA and PNA) are first-generation products 200 formed from the oxidation of $\alpha$ - and $\beta$-pinene, the most 201 abundant monoterpenes, by hydroxyl radical $(\mathrm{OH}), \mathrm{O}_{3}$, or 202 
203 nitrate radical $\left(\mathrm{NO}_{3}\right) ;{ }^{11,47}$ 3-HGA and MBTCA are higher204 generation products. ${ }^{11,15}$ On a global scale, the majority of 205 monoterpene SOA is believed to be formed from initialization 206 reactions involving ozone rather than $\mathrm{OH}$ or $\mathrm{NO}_{3}$ radicals; ${ }^{48-50}$ 207 although $\mathrm{NO}_{3}$ chemistry is an important source at night and in 208 some regions, links between yields and atmospheric $\mathrm{NO}_{x}$ 209 concentrations are less clear than for isoprene SOA.

210 Total concentrations of these tracers range from 24 to 12,000 $211 \mathrm{pg} /$ g-ice (mean 1780; median 10th and 90th percentiles, 788, 21273.2 , and $418 \mathrm{pg} / \mathrm{g}$-ice, respectively) with pinic acid dominating 213 (Table S2). Concentrations of PA (mean 932, median 409 pg/ 214 g-ice) are double those (mean 482, median $281 \mathrm{pg} / \mathrm{g}$-ice) of 215 PNA, consistent with laboratory-reported relative yields of the 216 two species. $^{48}$ 3-HGA and MBTCA are less abundant than PA 217 and PNA with a median ratio of (3-HGA + MBTCA):(PA + 218 PNA) of 0.09 (mean 0.15). The ratios (Figure 2F) were 219 significantly lower during the Little Ice Age $(\sim 0.03)$ than in the 220 preindustrial period $(0.16)$, reflecting the trends seen in total 221 organic carbon (TOC) concentrations (Figure 2C). The 222 average ratio $(0.18)$ for the last 100 years is higher (Table $223 \mathrm{~S} 2$ ), and while not significantly different from preindustrial 224 levels, appears to show an increasing trend (Figure 2F).

225 Ice core profiles of monoterpene and isoprene SOA tracers 226 are similar (Figure 2A,B), with monoterpene-derived SOA 227 tending to dominate (mean ratios of total monoterpene:total 228 isoprene tracers 2.6, median 1.4). Concentrations of PA and 229 PNA, in particular, resemble those of isoprene SOA tracers, 230 although there were substantial fluctuations in the relative 231 abundances. Ratios of PA and PNA (from monoterpene 232 oxidation) to 2-MT (from isoprene oxidation under low- $\mathrm{NO}_{x}$ 233 conditions) were similar (mean 2.3, median 1.2; Figure 2G), 234 suggesting isoprene and monoterpene SOA at Ushkovsky were 235 derived from similar source regions during the period covered 236 by the ice core samples.

\section{DISCUSSION}

238 Concentrations and relative abundances of the isoprene and 239 monoterpene SOA tracers detected in the Ushkovsky ice core 240 are determined by the combination of local BVOC sources and 241 long-range transport of both the tracers and their precursors 242 including reactive nitrogen. Emission rates of BVOCs are 243 strongly dependent on plant species and distribution and 244 environmental conditions such as temperature and light levels. 245 Transport of atmospheric compounds to the region is 246 influenced by the origin of the air mass arriving at the sample 247 site, which is determined by prevailing air circulation in the 248 Northern Hemisphere. Understanding and identifying the 249 relative contributions of the various sources and the causes of 250 the fluctuations in the ice core concentrations is vital to 251 ongoing efforts to elucidate and predict the evolution of 252 tropospheric composition and climate.

253 The general trends of isoprene and monoterpene SOA 254 tracers in the Ushkovsky ice core agree with climate records 255 such as mean annual temperature records from China and the 256 warm season temperature from Northern Siberia ${ }^{51}$ (Figure 2E). 257 As would be expected given the exponential temperature 258 dependence of biogenic emissions on temperature, concen259 trations of biogenic SOA tracers and TOC were low during the 260 Little Ice Age. Our ice core records of monoterpene SOA 261 tracers significantly correlate with historical temperatures in 262 proximal regions climate records including Chinese and 263 Northern Siberian temperatures $(r=0.63$ to $0.40, p<0.01)$ 264 (Table S3). However, isoprene SOA tracers showed relatively weak correlations with mean annual temperature in China and 265 Siberia $(r=0.54$ to $0.35, p<0.01)$. Relatively higher 266 correlations of the ice core SOA tracers with the Chinese 267 temperatures $(r=0.63$ to $0.47, p<0.01$ ) than those with 268 summer temperatures in Northern Siberia $(r=0.59$ to $0.35, p<269$ 0.01 ) suggest a strong empirical relationship between the ice 270 core records of biogenic SOA and midlatitude climate. 271 However, the historical temperature change in this region 272 $\left(\sim 1{ }^{\circ} \mathrm{C}\right)$ is too small to account fully for the large variations of 273 biogenic SOA tracers observed in the ice core samples during 274 the past 300 years.

275

The SOA tracers generally show very little correlation with 276 solar irradiance $(r=0.25$ to $0.32, p<0.05$ for isoprene tracers, 277 $\mathrm{PA}$ and PNA), although the higher generation monoterpene 278 tracers (3-HGA and MBTCA) may be weakly influenced ( $r=279$ 0.42 to $0.45, p<0.01)$. Although isoprene emissions are 280 strongly light dependent, those of most monoterpenes are 281 driven only by temperature, ${ }^{36,52}$ and it is likely that the 282 correlations seen are driven by the effect of solar irradiance on 283 subsequent photochemistry combined with relationships 284 between solar irradiance and surface temperature. The effect 285 of changes in solar forcing on surface temperature is highly 286 uncertain and also highly localized, ${ }^{53}$ making it hard to draw 287 firm conclusions on causality.

288

This variability is likely to be driven primarily by fluctuations 289 in atmospheric circulation patterns driven by the warm-season 290 Arctic Oscillation $(\mathrm{AO})^{54}$ (Figure 2D). All the ice core records 291 of biogenic SOA tracers correlate well with the AO index $(r=292$ 0.51 to $0.43, p<0.01$ ) (Table S3); for example, lower 293 concentrations of isoprene and monoterpene SOA tracers were 294 observed in 1693, the early-to-middle 1800s, and early 20th 295 century coincident with negative AO conditions, which reduce 296 westerly jet intensity and deliver cold and clean air masses from 297 the Arctic to middle and high latitudes in the Northern 298 Hemisphere. Under such conditions, not only are local biogenic 299 emissions low but also SOA tracer compounds and precursors 300 are not advected from more distant sources. High concen- 301 trations of biogenic SOA tracers in samples dating from the 302 early 18th century and present day (the 20th century) (Table 303 S2) occur during periods with the positive AO patterns. Under 304 such circulation patterns, air masses at Ushkovsky originate 305 mainly from lower latitudes in Asia, bringing warmer (and for 306 the present day, more polluted) conditions.

Biogenic isoprene SOA tracers at the beginning of the 18th 308 century were more abundant than those of the present day 309 (Table S2). The high levels of biogenic SOA tracers in the 310 preindustrial period relative to the present day were probably 311 caused by atmospheric transport and deposition of the tracers 312 to high latitudinal regions in the Northern Hemisphere during a 313 period when the lower latitudes were still thickly forested. 314 Anthropogenic emissions (of $\mathrm{NO}_{x}$ and sulfate in particular) are 315 known to play a strong role in enhancing biogenic SOA from 316 isoprene and to a lesser extent monoterpenes, ${ }^{55,56}$ but our 317 findings indicate other factors contribute substantially to the 318 total SOA at Ushkovsky. This is to be expected given the 319 myriad of factors that contribute to SOA formation, evolution, 320 and transport, and the highly complex and nonlinear nature of 321 atmospheric chemistry and SOA formation in particular. Short- 322 and long-term changes in climate and land cover alter biogenic 323 emissions from local source regions. Global development has 324 altered emission rates and concentrations of anthropogenic 325 pollutants. Natural variability in middle- to high-latitude 326 atmospheric dynamics and circulation patterns shifts the source 327 
328 regions of transported species. Differences in temperature affect 329 the rates of the all the various processes involved to greater and 330 lesser extents. The extreme complexity of the dependencies and 331 relationships between these competing processes further 332 emphasizes the need for data sets such as the ice core records 333 presented here to constrain emissions and elucidate the 334 processes involved in chemical transformation and transport 335 over long time scales.

336 Biomass burning is one of the most important emission 337 sources of gases and particles into the atmosphere. ${ }^{57,58}$ Like 338 those of 2-methyltetrols and 2-MGA, relatively high concen339 trations of monoterpene SOA tracers were found at Ushkovsky 340 in 1949. In the same ice core, Kawamura et al. ${ }^{4}$ reported the 341 highest concentration (18.6 ng/g-ice) of levoglucosan, a 342 biomass-burning tracer, ${ }^{59}$ in the year 1949. Interestingly, the 343 intensive biomass-burning episode in 1949 may have been 344 associated with the civil war that spread out all over 345 northeastern to central China in the period 1948-1949. 346 During the war fires, much land vegetation was burned in these 347 regions, generating massive amounts of smoke aerosols and 348 VOCs including isoprene, ${ }^{58}$ which could have contributed to 349 the peak of biogenic SOA tracers in 1949. Recent smog 350 chamber experiments have demonstrated that nonmethane 351 organic gases from combustion sources are a major class of 352 SOA precursors. ${ }^{60}$ Positive correlations were found between 353 levoglucosan and a few higher generation oxidation products 354 (e.g., 3-HGA and MBTCA) in the Ushkovsky ice core (Table 355 S4), suggesting that biomass-burning activities have had 356 sporadic influence in Northeast Asia, especially for mono357 terpene SOA tracers.

358 The ratios of PA and PNA (monoterpene SOA tracers) to 2359 MT (isoprene SOA tracers associated with low $\mathrm{NO}_{x}$ 360 conditions) are not significantly higher in the present day 361 samples (mean 2.7, median 1.7) than the preindustrial period 362 (mean 2.4, median 0.84; Table S2), in spite of increasing $\mathrm{NO}_{x}$ 363 concentrations in source regions. This indicates concomitant 364 changes in BVOC concentrations at the site and in source 365 regions, pointing to the complexity of disentangling the 366 contributory factors. BVOC emissions at high latitudes tend 367 to be dominated by monoterpenes due to plant species 368 distribution. Monoterpene SOA tracers would therefore be 369 expected to be more abundant relative to isoprene SOA tracers 370 during periods when air masses to the region originate in the 371 Arctic regions. The relatively high average ratio of (PNA + 372 PA)/2-MT (mean 3.8, median 1.2) found during the Little Ice 373 Age is therefore likely a reflection of air mass origin, ${ }^{15,37,61}$ in 374 keeping with the extremely cold conditions experienced in 375 Europe at this time.

376 The 20th century concentrations of isoprene SOA tracers in 377 the Ushkovsky ice core (mean $1060 \pm 1120 \mathrm{pg} / \mathrm{g}$-ice) are 378 substantially lower (although not significantly so, due to the 379 high fluctuations observed during both periods) than those of 380 the preindustrial period (mean $2390 \pm 3260 \mathrm{pg} / \mathrm{g}$-ice), whereas 381 concentrations of monoterpene SOA tracers show little 382 difference (Table S2). Given other indications that biogenic 383 SOA in this region is mostly derived from local sources, this 384 suggests a significant decrease in isoprene emissions at 385 Northern Hemisphere high latitudes, especially in East Asia. 386 This may be a result of the substantial rise in $\mathrm{CO}_{2}$ levels 387 (elevated atmospheric concentrations of $\mathrm{CO}_{2}$ have been shown 388 to directly inhibit isoprene emissions ${ }^{62}$ ) coupled with land-use 389 change from broadleaf forests (high isoprene emitters) to 390 croplands (negligible isoprene emitters) since the industrial revolution. ${ }^{35}$ Model hindcasts show decreased annual global 391 isoprene emissions and increased monoterpene emissions from 392 the preindustrial era to the present day. ${ }^{63}$

In addition to the factors outlined above, small-scale 394 meteorological, biochemical, and in situ glacial processes can 395 be expected to contribute to the large historical variations of 396 organics in the ice core. Local meteorological phenomena such 397 as land/sea breezes and orographic uplift will regulate local 398 transport of aerosol particles and their precursors to the 399 Ushkovsky ice cap, as observed at Mt. Fuji (3776 m a.s.l.). ${ }^{64} 400$ Photochemical and biological aging of organic aerosols after 401 their deposition at the snow/glacier surfaces are also known to 402 modify ice core organics. ${ }^{3,65,66}$ Thus, organics recorded in ice 403 cores are a function of variations in external inputs of 404 atmospheric aerosols and potentially in situ processes such as 405 accumulation rates, summer melt events, and microbial 406 activities. $^{7}$ However, the accumulation rates in the ice cores 407 do not significantly change over the studied periods compared 408 to the concentrations of biogenic SOA tracers. ${ }^{33,67}$ Seki et al. ${ }^{7} 409$ also stated that the TOC and biogenic primary organic tracers 410 in the same ice core samples do not significantly correlate with 411 measured melt events. ${ }^{68}$ Thus, the concentrations of biogenic 412 SOA tracers in the Ushkovsky ice core are not significantly 413 biased by the accumulation rates and/or summer melt events. 414

The historical reconstruction of BVOC emissions and 415 biogenic SOA production is a highly complex and challenging 416 issue, regulated by many factors, including species distribution, 417 climate, the chemical composition of the atmosphere (e.g., 418 concentrations of $\mathrm{CO}_{2}, \mathrm{NO}_{x}$, and $\left.\mathrm{O}_{3}\right),{ }^{42,69}$ and large-scale 419 atmospheric circulation. In addition, humans have altered the 420 Earth's environment with unprecedented intensity and speed 421 through land-use changes and anthropogenic emissions since 422 the industrial revolution. Given the multiplicity of factors 423 influencing SOA concentrations and properties, the substantial 424 uncertainties in current estimates of aerosol radiative forcing 425 and climate effect is unsurprising. Our ice core records provide 426 important information on biogenic SOA concentrations over 427 the past 300 years that will allow us to begin to disentangle the 428 causes of observed trends and fluctuations in atmospheric 429 aerosols and gain vital insights into the various processes 430 involved. These data are particularly useful for modelers to 431 evaluate the skill of current atmospheric chemistry and 432 transport and Earth system models to reproduce aerosol 433 concentrations under historical pristine conditions in the 434 Northern Hemisphere. The understanding gained from such 435 model-measurement comparisons will allow us to constrain 436 projections of future concentrations and hence the potential 437 influence of biogenic SOA on future climate change.

\section{ASSOCIATED CONTENT}

439

S Supporting Information

440

The Supporting Information is available free of charge on the 441 ACS Publications website at DOI: 10.1021/acs.estlett.6b00275. 442

Detailed methodology and four supplementary tables 443 (Table S1-S4). (PDF)

\section{AUTHOR INFORMATION}

445

Corresponding Author

446

*Phone: +86-10-8201-3200. E-mail: fupingqing@mail.iap.ac.cn. 447

Notes

448

The authors declare no competing financial interest.

\section{(1)}




\section{$450 \square$ ACKNOWLEDGMENTS}

451 This work was partly supported by the Japan Society for the 452 Promotion of Science (JSPS), the Japanese Ministry of 453 Education, Culture, Sports, Science and Technology (MEXT) 454 through Grant-in-aid Nos. 14204055 and 24221001, National 455 Natural Science Foundation of China (Grant No. 41475117), 456 and the "One Hundred Talents" program of the Chinese 457 Academy of Sciences.

\section{REFERENCES}

459 (1) Jones, P. D.; Mann, M. E. Climate over past millennia. Rev. 460 Geophys. 2004, 42, 2013RG000143.

461 (2) Legrand, M.; Preunkert, S.; Schock, M.; Cerqueira, M.; Kasper462 Giebl, A.; Afonso, J.; Pio, C.; Gelencsér, A.; Dombrowski-Etchevers, I. 463 Major 20th century changes of carbonaceous aerosol components 464 (EC, WinOC, DOC, HULIS, carboxylic acids, and cellulose) derived 465 from Alpine ice cores. J. Geophys. Res. 2007, 112, D23S11.

466 (3) McNeill, V. F.; Grannas, A. M.; Abbatt, J. P. D.; Ammann, M.; 467 Ariya, P.; Bartels-Rausch, T.; Domine, F.; Donaldson, D. J.; Guzman, 468 M. I.; Heger, D.; Kahan, T. F.; Klan, P.; Masclin, S.; Toubin, C.; 469 Voisin, D. Organics in environmental ices: sources, chemistry, and 470 impacts. Atmos. Chem. Phys. 2012, 12, 9653-9678.

471 (4) Kawamura, K.; Izawa, Y.; Mochida, M.; Shiraiwa, T. Ice core 472 records of biomass burning tracers (levoglucosan and dehydroabietic, 473 vanillic and p-hydroxybenzoic acids) and total organic carbon for past 474300 years in the Kamchatka Peninsula, Northeast Asia. Geochim. 475 Cosmochim. Acta 2012, 99, 317-329.

476 (5) Guilhermet, J.; Preunkert, S.; Voisin, D.; Baduel, C.; Legrand, M. 477 Major 20th century changes of water-soluble humic-like substances 478 (HULISws) aerosol over Europe inferred from Apline ice cores. J. 479 Geophys. Res. - Atmos. 2013, 118, 3869-3878.

480 (6) Kawamura, K.; Yokoyama, K.; Fujii, Y.; Watanabe, O. A 481 Greenland ice core record of low molecular weight dicarboxylic 482 acids, ketocarboxylic acids, and alpha-dicarbonyls: A trend from Little 483 Ice Age to the present (1540 to 1989 AD). J. Geophys. Res., [Atmos] 484 2001, 106 (D1), 1331-1345.

485 (7) Seki, O.; Kawamura, K.; Bendle, J. A. P.; Izawa, Y.; Suzuki, I.; 486 Shiraiwa, T.; Fujii, Y. Carbonaceous aerosol tracers in ice-cores record 487 multi-decadal climate oscillations. Sci. Rep. 2015, 5, 14450.

488 (8) Andreae, M. O. Aerosols before pollution. Science 2007, 315, 5048951.

490 (9) Guenther, A. B.; Jiang, X.; Heald, C. L.; Sakulyanontvittaya, T.; 491 Duhl, T.; Emmons, L. K.; Wang, X. The Model of Emissions of Gases 492 and Aerosols from Nature version 2.1 (MEGAN2.1): an extended and 493 updated framework for modeling biogenic emissions. Geosci. Model 494 Dev. 2012, 5, 1471-1492.

495 (10) Went, F. W. Blue hazes in the atmosphere. Nature 1960, 187, $496641-643$.

497 (11) Hallquist, M.; Wenger, J. C.; Baltensperger, U.; Rudich, Y.; 498 Simpson, D.; Claeys, M.; Dommen, J.; Donahue, N. M.; George, C. 499 Goldstein, A. H.; Hamilton, J. F.; Herrmann, H.; Hoffmann, T.; 500 Iinuma, Y.; Jang, M.; Jenkin, M.; Jimenez, J. L.; Kiendler-Scharr, A.; 501 Maenhaut, W.; McFiggans, G.; Mentel, T. F.; Monod, A.; Prévôt, A. S. 502 H.; Seinfeld, J. H.; Surratt, J. D.; Szmigielski, R.; Wildt, J. The 503 formation, properties and impact of secondary organic aerosol: current 504 and emerging issues. Atmos. Chem. Phys. 2009, 9, 5155-5235.

505 (12) Pöschl, U. Atmospheric aerosols: Composition, transformation, 506 climate and health effects. Angew. Chem., Int. Ed. 2005, 44, 7520-7540. 507 (13) Kanakidou, M.; Seinfeld, J. H.; Pandis, S. N.; Barnes, I.; 508 Dentener, F. J.; Facchini, M. C.; Van Dingenen, R.; Ervens, B.; Nenes, 509 A.; Nielsen, C. J.; Swietlicki, E.; Putaud, J. P.; Balkanski, Y.; Fuzzi, S. 510 Horth, J.; Moortgat, G. K.; Winterhalter, R.; Myhre, C. E. L.; 511 Tsigaridis, K.; Vignati, E.; Stephanou, E. G.; Wilson, J. Organic aerosol 512 and global climate modelling: a review. Atmos. Chem. Phys. 2005, 5, 513 1053-1123.

514 (14) Pöschl, U.; Martin, S. T.; Sinha, B.; Chen, Q.; Gunthe, S. S.; 515 Huffman, J. A.; Borrmann, S.; Farmer, D. K.; Garland, R. M.; Helas, 516 G.; Jimenez, J. L.; King, S. M.; Manzi, A.; Mikhailov, E.; Pauliquevis,
T.; Petters, M. D.; Prenni, A. J.; Roldin, P.; Rose, D.; Schneider, J.; Su, 517 H.; Zorn, S. R.; Artaxo, P.; Andreae, M. O. Rainforest aerosols as 518 biogenic nuclei of clouds and precipitation in the Amazon. Science 519 2010, 329, 1513-1516.

(15) Jimenez, J. L.; Canagaratna, M. R.; Donahue, N. M.; Prevot, A. 521 S. H.; Zhang, Q.; Kroll, J. H.; DeCarlo, P. F.; Allan, J. D.; Coe, H.; Ng, 522 N. L.; Aiken, A. C.; Docherty, K. S.; Ulbrich, I. M.; Grieshop, A. P.; 523 Robinson, A. L.; Duplissy, J.; Smith, J. D.; Wilson, K. R.; Lanz, V. A.; 524 Hueglin, C.; Sun, Y. L.; Tian, J.; Laaksonen, A.; Raatikainen, T.; 525 Rautiainen, J.; Vaattovaara, P.; Ehn, M.; Kulmala, M.; Tomlinson, J. 526 M.; Collins, D. R.; Cubison, M. J.; Dunlea, E. J.; Huffman, J. A.; 527 Onasch, T. B.; Alfarra, M. R.; Williams, P. I.; Bower, K.; Kondo, Y.; 528 Schneider, J.; Drewnick, F.; Borrmann, S.; Weimer, S.; Demerjian, K.; 529 Salcedo, D.; Cottrell, L.; Griffin, R.; Takami, A.; Miyoshi, T.; 530 Hatakeyama, S.; Shimono, A.; Sun, J. Y.; Zhang, Y. M.; Dzepina, K.; 531 Kimmel, J. R.; Sueper, D.; Jayne, J. T.; Herndon, S. C.; Trimborn, A. 532 M.; Williams, L. R.; Wood, E. C.; Middlebrook, A. M.; Kolb, C. E.; 533 Baltensperger, U.; Worsnop, D. R. Evolution of organic aerosols in the 534 atmosphere. Science 2009, 326 (5959), 1525-1529.

(16) Robinson, A. L.; Donahue, N. M.; Shrivastava, M. K.; 536 Weitkamp, E. A.; Sage, A. M.; Grieshop, A. P.; Lane, T. E.; Pierce, 537 J. R.; Pandis, S. N. Rethinking organic aerosols: Semivolatile emissions 538 and photochemical aging. Science 2007, 315, 1259-1262.

(17) Tunved, P.; Hansson, H.-C.; Kerminen, V.-M.; Ström, J.; Dal 540 Maso, M.; Lihavainen, H.; Viisanen, Y.; Aalto, P. P.; Komppula, M.; 541 Kulmala, M. High natural aerosol loading over boreal forests. Science 542 2006, 312, 261-263.

(18) Meskhidze, N.; Nenes, A. Phytoplankton and cloudiness in the 544 Southern Ocean. Science 2006, 314 (5804), 1419-1423.

(19) Goldstein, A. H.; Galbally, I. E. Known and unexplored organic 546 constituents in the Earth's atmosphere. Environ. Sci. Technol. 2007, 41547 (5), 1514-1521.

(20) Heald, C. L.; Kroll, J. H.; Jimenez, J. L.; Docherty, K. S.; 549 DeCarlo, P. F.; Aiken, A. C.; Chen, Q.; Martin, S. T.; Farmer, D. K.; 550 Artaxo, P. A simplified description of the evolution of organic aerosol 551 composition in the atmosphere. Geophys. Res. Lett. 2010, 37, L08803. 552

(21) Tsigaridis, K.; Kanakidou, M. Global modelling of secondary 553 organic aerosol in the troposphere: A sensitivity analysis. Atmos. Chem. 554 Phys. Discuss. 2003, 3, 2879-2929.

(22) Myhre, G.; Shindell, D.; Breón, F.-M.; Collins, W.; Fuglestvedt, 556 J.; Huang, J.; Koch, D.; Lamarque, J.-F.; Lee, D.; Mendoza, B.; 557 Nakajima, T.; Robock, A.; Stephens, G.; Zhang, H. Anthropogenic and 558 Natural Radiative Forcing. In Stocker, T.; Qin, D. H.; Plattner, G. K., 559 Eds.; Climate Change 2013: The Physical Science Basis. Contribution of 560 Working Group I to the Fifth Assessment Report of the Intergovernmental 561 Panel on Climate Change, Cambridge University Press; Cambridge, 562 2013.

(23) Chung, S. H.; Seinfeld, J. H. Global distribution and climate 564 forcing of carbonaceous aerosols. J. Geophys. Res. [Atmos] 2002, 107565 (D19), na DOI: 10.1029/2001JD001397.

(24) Claeys, M.; Graham, B.; Vas, G.; Wang, W.; Vermeylen, R.; 567 Pashynska, V.; Cafmeyer, J.; Guyon, P.; Andreae, M. O.; Artaxo, P.; 568 Maenhaut, W. Formation of secondary organic aerosols through 569 photooxidation of isoprene. Science 2004, 303 (5661), 1173-1176. 570

(25) Surratt, J. D.; Murphy, S. M.; Kroll, J. H.; Ng, N. L.; 571 Hildebrandt, L.; Sorooshian, A.; Szmigielski, R.; Vermeylen, R.; 572 Maenhaut, W.; Claeys, M.; Flagan, R. C.; Seinfeld, J. H. Chemical 573 composition of secondary organic aerosol formed from the photo- 574 oxidation of isoprene. J. Phys. Chem. A 2006, 110 (31), 9665-9690. 575

(26) Perraud, V.; Bruns, E. A.; Ezell, M. J.; Johnson, S. N.; Yu, Y.; 576 Alexander, M. L.; Zelenyuk, A.; Imre, D.; Chang, W. L.; Dabdub, D.; 577 Pankow, J. F.; Finlayson-Pitts, B. J. Nonequilibrium atmospheric 578 secondary organic aeosol formation and growth. Proc. Natl. Acad. Sci. 579 U. S. A. 2012, 109 (8), 2836-2841.

(27) Ehn, M.; Thornton, J. A.; Kleist, E.; Sipilä, M.; Junninen, H.; 581 Pullinen, I.; Springer, M.; Rubach, F.; TIllmann, R.; Lee, B.; Lopez- 582 Hilfiker, F.; Andres, S.; Acir, I.-H.; Rissanen, M.; Jokinen, T.; 583 Schobesberger, S.; Kangasluoma, J.; Kontkanen, J.; Nieminen, T.; 584 Kurtén, T.; Nielsen, L. B.; Jørgensen, S.; Kjaergaard, H. G.; 585 
586 Canagaratna, M.; Dal Maso, M.; Berndt, T.; Petäjä, T.; Wahner, A.; 587 Kerminen, V.-M.; Kulmala, M.; Worsnop, D. R.; Wildt, J.; Mentel, T. 588 F. A large source of low-volatility secondary organic aerosol. Nature 589 2014, 506, 476-479.

590 (28) Goldstein, A. H.; Koven, C. D.; Heald, C. L.; Fung, I. Y. 591 Biogenic carbon and anthropogenic pollutants combine to form a 592 cooling haze over the southeastern United States. Proc. Natl. Acad. Sci. 593 U. S. A. 2009, 106, 8835-8840.

594 (29) Kuwata, M.; Martin, S. T. Phase of atmospheric secondary 595 organic material affects its reactivity. Proc. Natl. Acad. Sci. U. S. A. 2012, 596109 (43), 17354-17359.

597 (30) Shiraiwa, M.; Yee, L. D.; Schilling, K. A.; Loza, C. L.; Craven, J. 598 S.; Zuend, A.; Ziemann, P. J.; Seinfeld, J. H. Size distribution dynamics 599 reveal particle-phase chemistry in organic aerosol formation. Proc. Natl. 600 Acad. Sci. U. S. A. 2013, 110 (29), 11746-11750.

601 (31) Tsigaridis, K.; Krol, M.; Dentener, F. J.; Balkanski, Y.; Lathiere, 602 J.; Metzger, S.; Hauglustaine, D. A.; Kanakidou, M. Change in global 603 aerosol composition since preindustrial times. Atmos. Chem. Phys. 604 2006, 6, 5143-5162.

605 (32) Tsigaridis, K.; Kanakidou, M. Secondary organic aerosol 606 importance in the future atmosphere. Atmos. Environ. 2007, 41 (22), $6074682-4692$.

608 (33) Shiraiwa, T.; Murav'yev, Y. D.; Kameda, T.; Nishio, F.; Toyama, 609 Y.; Takahashi, A.; Ovsyannikov, A. A.; Salamatin, A. N.; Yamagata, K. 610 Characteristics of a crater glacier at Ushkovsky volcano, Kamchatka, 611 Russia, as revealed by the physical perperties of ice cores and borehole 612 thermometry. J. Glaciol. 2001, 47 (158), 423-432.

613 (34) Szmigielski, R.; Surratt, J. D.; Gómez-González, G.; Van der 614 Veken, P.; Kourtchev, I.; Vermeylen, R.; Blockhuys, F.; Jaoui, M.; 615 Kleindienst, T. E.; Lewandowski, M.; Offenberg, J. H.; Edney, E. O.; 616 Seinfeld, J. H.; Maenhaut, W.; Claeys, M. 3-Methyl-1,2,3-butane617 tricarboxylic acid: An atmospheric tracer for terpene secondary organic 618 aerosol. Geophys. Res. Lett. 2007, 34, L24811.

619 (35) Tanaka, K.; Kim, H.-J.; Saito, K.; Takahashi, H. G.; Watanabe, 620 M.; Yokohata, T.; Kimoto, M.; Takata, K.; Yasunari, T. How have both 621 cultivation and warming influenced annual global isoprene and 622 monoterpene emissions since the preindustrial era? Atmos. Chem. 623 Phys. 2012, 12, 9703-9718.

624 (36) Guenther, A.; Hewitt, C. N.; Erickson, D.; Fall, R.; Geron, C.; 625 Graedel, T.; Harley, P.; Klinger, L.; Lerdau, M.; McKay, W. A.; Pierce, 626 T.; Scholes, B.; Steinbrecher, R.; Tallamraju, R.; Taylor, J.; 627 Zimmerman, P. A global model of natural volatile organic compound 628 emissions. J. Geophys. Res. 1995, 100 (D5), 8873-8892.

629 (37) Guenther, A.; Karl, T.; Harley, P.; Wiedinmyer, C.; Palmer, P. I.; 630 Geron, C. Estimates of global terrestrial isoprene emissions using 631 MEGAN (Model of Emissions of Gases and Aerosols from Nature). 632 Atmos. Chem. Phys. 2006, 6, 3181-3210.

633 (38) Henze, D. K.; Seinfeld, J. H. Global secondary organic aerosol 634 from isoprene oxidation. Geophys. Res. Lett. 2006, 33, L09812.

635 (39) Surratt, J. D.; Chan, A. W. H.; Eddingsaas, N. C.; Chan, M. N.; 636 Loza, C. L.; Kwan, A. J.; Hersey, S. P.; Flagan, R. C.; Wennberg, P. O.; 637 Seinfeld, J. H. Reactive intermediates revealed in secondary organic 638 aerosol formation from isoprene. Proc. Natl. Acad. Sci. U. S. A. 2010, 639107 (15), 6640-6645.

640 (40) Nguyen, T. B.; Bates, K. H.; Crounse, J. D.; Schwantes, R. H.; 641 Zhang, X.; Kjaergaard, H. G.; Surratt, J. D.; Lin, P.; Laskin, A.; 642 Seinfeld, J. H.; Wennberg, P. O. Mechanism of the hydroxyl radical 643 oxidation of methacryloyl peroxynitrate (MPAN) and its pathway 644 toward secondary organic aerosol formation in the atmosphere. Phys. 645 Chem. Chem. Phys. 2015, 17 (27), 17914-17926.

646 (41) Lin, Y. H.; Zhang, H.; Pye, H. O. T.; Zhang, Z.; Marth, W. J.; 647 Park, S.; Arashiro, M.; Cui, T.; Budisulistiorini, S. H.; Sexton, K. G.; 648 Vizuete, W.; Xie, Y.; Luecken, D. J.; Piletic, I. R.; Edney, E. O.; 649 Bartolotti, L. J.; Gold, A.; Surratt, J. D. Epoxide as a precursor to 650 secondary organic aerosol formation from isoprene photooxidation in 651 the present of nitrogen oxides. Proc. Natl. Acad. Sci. U. S. A. 2013, 110, $6526718-6723$.

653 (42) Pacifico, F.; Folberth, G. A.; Jones, C. D.; Harrison, S. P.; 654 Collins, W. J. Sensitivity of biogenic isoprene emissions to past, present, and future environmental conditions and implications for 655 atmospheric chemistry. J. Geophys. Res., [Atmos] 2012, 117, D22302. 656 (43) Murray, L. T.; Mickley, L. J.; Kaplan, J. O.; Sofen, E. D.; Pfeiffer, 657 M.; Alexander, B. Factors controlling variability in the oxidative 658 capacity of the troposphere sicne the Last Glacial Maximum. Atmos. 659 Chem. Phys. 2014, 14, 3589-3622.

(44) Paulot, F.; Crounse, J. D.; Kjaergaard, H. G.; Kurten, A.; St. 661 Clair, J. M.; Seinfeld, J. H.; Wennberg, P. O. Unexpected epoxide 662 formation in the gas-phase photooxidation of isoprene. Science 2009, 663 325 (5941), 730-733.

(45) Carlton, A. G.; Bhave, P. V.; Napelenok, S. L.; Edney, E. O.; 665 Sarwar, G.; Pinder, R. W.; Pouliot, G.; Houyoux, M. Model 666 representation of secondary organic aerosol in CMAQv4.7. Environ. 667 Sci. Technol. 2010, 44 (22), 8553-8560.

(46) Worton, D. R.; Surratt, J. D.; Lafranchi, B. W.; Chan, A. W. H.; 669 Zhao, Y.; Weber, R. J.; Park, J. H.; Gilman, J. B.; de Gouw, J.; Park, C.; 670 Schade, G.; Beaver, M.; St. Clair, J. M.; Crounse, J.; Wennberg, P.; 671 Wolfe, G. M.; Harrold, S.; Thornton, J. A.; Farmer, D. K.; Docherty, K. 672 S.; Cubison, M. J.; Jimenez, J. L.; Frossard, A. A.; Russell, L. M.; 673 Kristensen, K.; Glasius, M.; Mao, J.; Ren, X.; Brune, W.; Browne, E. C.; 674 Pusede, S. E.; Cohen, R. C.; Seinfeld, J. H.; Goldstein, A. H. 675 Observational insights into aerosol formation from isoprene. Environ. 676 Sci. Technol. 2013, 47 (20), 11403-11413.

(47) Larsen, B. R.; Di Bella, D.; Glasius, M.; Winterhalter, R.; Jensen, 678 N. R; Hjorth, J. Gas-phase OH oxidation of monoterpenes: Gaseous 679 and particulate products. J. Atmos. Chem. 2001, 38 (3), 231-276. 680

(48) Ma, Y.; Willcox, T. R.; Russell, A. T.; Marston, G. Pinic and 681 pinonic acid formation in the reaction of ozone with $\alpha$-pinene. Chem. 682 Commun. 2007, 13, 1328-1330.

(49) Fry, J. L.; Sackinger, K. Model investigation of NO3 secondary 684 organic aerosol (SOA) source and heterogeneous organic aerosol 685 (OA) sink in the western United States. Atmos. Chem. Phys. 2012, 12, 686 8797-8811.

(50) Pye, H. O. T.; Chan, A. W. H.; Barkley, M. P.; Seinfeld, J. H. 688 Global modeling of organic aerosol: the importance of reactive 689 nitrogen (NOx and NO3). Atmos. Chem. Phys. 2010, 10 (22), 11261- 690 11276.

(51) Ljungqvist, F. C. A regional approach to the medieval warm 692 period and the little ice age. In Simard, S.; Austin, M. E., Eds.; Climate 693 Change and Variability; Sciyo, Croatia, 2010.

(52) Gröte, R.; Niinemets, U. Modeling volatile isoprenoid emissions 695 - a story with split ends. Plant Biol. 2008, 10 (1), 8-28. 696

(53) Le, T. Solar forcing of Earth's surface temperature in PMIP3 697 simulations of the last millennium. Atmos. Sci. Lett. 2015, 16 (3), 285- 698 290.

(54) D’Arrigo, R. D.; Cook, E. R.; Mann, M. E.; Jacoby, G. C. Tree- 700 ring reconstructions of temperature and sea-level pressure variability 701 associated with the warm-season Arctic Oscillation since $\mathrm{AD}$ 1650. 702 Geophys. Res. Lett. 2003, 30 (11), 1549.

(55) Shilling, J. E.; Zaveri, R. A.; Fast, J. D.; Kleinman, L.; Alexander, 704 M. L.; Canagaratna, M. R.; Fortner, E.; Hubbe, J. M.; Jayne, J. T.; 705 Sedlacek, A.; Setyan, A.; Springston, S.; Worsnop, D. R.; Zhang, Q. 706 Enhanced SOA formation from mixed anthropogenic and biogenic 707 emissions during the CARES campaign. Atmos. Chem. Phys. 2013, 13, 708 2091-2113.

(56) Rollins, A. W.; Browne, E. C.; Min, K.-E.; Pusede, S. E.; 710 Wooldridge, P. J.; Gentner, D. R.; Goldstein, A. H.; Liu, S.; Day, D. A.; 711 Russell, L. M.; Cohen, R. C. Evidence for NOx control over nighttime 712 SOA formation. Science 2012, 337, 1210-1212.

(57) Crutzen, P. J.; Andreae, M. O. Biomass burning in the tropics: 714 Impact on atmospheric chemistry and biogeochemical cycles. Science 715 1990, 250, 1669-1678.

(58) Andreae, M. O.; Merlet, P. Emission of trace gases and aerosols 717 from biomass burning. Global Biogeochem. Cycles 2001, 15 (4), 955- 718 966.

(59) Simoneit, B. R. T.; Schauer, J. J.; Nolte, C. G.; Oros, D. R.; Elias, 720 V. O.; Fraser, M. P.; Rogge, W. F.; Cass, G. R. Levoglucosan, a tracer 721 for cellulose in biomass burning and atmospheric particles. Atmos. 722 Environ. 1999, 33 (2), 173-182. 
724 (60) Jathar, S. H.; Gordon, T. D.; Hennigan, C. J.; Pye, H. O.; 725 Pouliot, G.; Adams, P. J.; Donahue, N. M.; Robinson, A. L. 726 Unspeciated organic emissions from combustion sources and their 727 influence on the secondary organic aerosol budget in the United 728 States. Proc. Natl. Acad. Sci. U. S. A. 2014, 111 (29), 10473-10478.

729 (61) Fu, P. Q.; Kawamura, K.; Chen, J.; Barrie, L. A. Isoprene, 730 monoterpene, and sesquiterpene oxidation products in the high Arctic 731 aerosols during late winter to early summer. Environ. Sci. Technol. 732 2009, 43 (11), 4022-4028.

733 (62) Wilkinson, M. J.; Monson, R. K.; Trahan, N.; Lee, S.; Brown, E.; 734 Jackson, R. B.; Polley, H. W.; Fay, P. A.; Fall, R. Leaf isoprene emission 735 rate as a function of atmospheric $\mathrm{CO} 2$ concentration. Glob. Change 736 Biol. 2009, 15 (5), 1189-1200.

737 (63) Lathière, J.; Hewitt, C. N.; Beerling, D. J. Sensitivity of isoprene 738 emissions from the terrestrial biosphere to 20th century changes in 739 atmospheric $\mathrm{CO}_{2}$ concentration, climate, and land use. Global 740 Biogeochem. Cy. 2010, 24, GB1004.

741 (64) Fu, P. Q.; Kawamura, K.; Chen, J.; Miyazaki, Y. Secondary 742 production of organic aerosols from biogenic VOCs over Mt. Fuji, 743 Japan. Environ. Sci. Technol. 2014, 48 (15), 8491-8497.

744 (65) Yao, T. D.; Xiang, S. R.; Zhang, X. J.; Wang, N. L.; Wang, Y. Q. 745 Microorganisms in the Malan ice core and their relation to climatic 746 and environmental changes. Global Biogeochem. Cycles 2006, 20, 747 GB1004.

748 (66) Zhang, S.; Hou, S.; Wu, Y.; Qin, D. Bacteria in Himalayan glacial 749 ice and its relationship to dust. Biogeosciences 2008, 5, 1741-1750.

750 (67) Shiraiwa, T.; Yamaguchi, S. Reconstruction of glacier mass 751 balance and climate changes in the Kamchatka Peninsula. Chigaku 752 Zasshi 2002, 111, 476-485.

753 (68) Solomina, O.; Wiles, G.; Shiraiwa, T.; D’Arrigo, R. Multiproxy 754 records of climate variability for Kamchatka for the past 400 years. 755 Clim. Past 2007, 3 (1), 119-128.

756 (69) Mahowald, N.; Ward, D. S.; Kloster, S.; Flanner, M. G.; Heald, 757 C. L.; Heavens, N. G.; Hess, P. G.; Lamarque, J.-F.; Chuang, P. Y. 758 Aerosol impacts on climate and biogeochemistry. Annu. Rev. Environ. 759 Resourc. 2011, 36, 45-74.

760 (70) Steinhilber, F.; Beer, J.; Fröhlich, C. Total solar irradiance 761 during the Holocene. Geophys. Res. Lett. 2009, 36, L19704. 